\title{
DROUGHT: THE ACHILLES HEEL OF THE ISLAMIC REPUBLIC OF IRAN
}

\author{
Afshin Shahi
}

Introduction

Over the last four decades, the Islamic Republic has been facing numerous internal and external security challenges. It has survived bloody post- revolutionary turmoil, eight years of destructive war with Iraq (where the majority of regional and global players backed Saddam Hussain) and paralysing regimes of US-led sanctions. Despite these significant challenges the Islamic Republic has managed to maintain control at home and assert itself as a major regional player. Despite this image of stability, both the Islamic Republic and the country at large will soon come up against the grave consequences of a long-standing but long-ignored crisis. The threat is not emanating from its regional adversaries, Israel and Saudi Arabia or the Islamic Republic's arch enemy, the United States. The enemy is within and is drastically changing the socio-economic fabric of Iranian society and is increasingly making the state vulnerable to unpredictable social eruptions. This enemy is none other than the pressing environmental challenges, which are manifesting themselves in the form of water bankruptcy, drought, desertification and ever-increasing temperatures - all of which are piling pressure on an already over- stretched governing system.

Due to gross water mismanagement and its damaging impact on the country, Iran faces the worst situation in water resources of any industrialised nation. ${ }^{1}$ Water depletion in Iran is one of the highest in the world, and the government expects a 25 per cent decline in surface water runoff by $2030 .^{2}$ The UN estimates that between the 1970 s and the year 2000 , groundwater extraction almost quadrupled, while the number of wells rose fivefold in Iran. ${ }^{3}$ In 2017, more than 540 cities were on the brink of water stress, and the problem only worsened in $2018 .{ }^{4}$ In 2017, only the northern provinces of Ardabil and Golestan experienced normal rain- fall. ${ }^{5}$ Meanwhile, some provinces such as Khuzestan have seen precipitation drop by 30-80 per cent. ${ }^{6}$ Even more, many Caspian regions that receive the highest rainfall in Iran have experienced considerable drops in precipitation. For example, in 2017, South Khorasan witnessed a decline of 81 percent in precipitation from the previous year. ${ }^{7}$ According to Iran's Meteorological Organisation, approximately 97 per cent of the country is experiencing drought conditions. Rivers and lakes are drying very fast. It is estimated that from 1985 to 2015, Lake Urmia, which once covered 2,000 square miles, shrunk by 90 per cent. Deserts have expanded and as a result millions of disfranchised farmers and herders have left the countryside to live in the miserable conditions of Iran's growing cities. Tens of thousands of villages have been deserted and most of the major urban centres have passed their limits to absorb more inhabitants. Some officials predict that in less than 25 years, 50 million Iranians will be displaced from their current homes because of the pressing ecological conditions. ${ }^{8}$

In recent years, the gap between the grassroots and the state has widened and there is an increasing dissatisfaction with governance plagued by systemic corruption, nepotism, economic 
mismanagement, unaccountability and a foreign policy which has produced various regional and trans- regional adversaries. These issues have significantly undermined the legitimacy of the Islamic Republic 40 years after its establishment. The recent environmentally-induced conflicts in the Middle East have high- lighted the fact that in the absence of legitimacy, the state may be per- ceived as part of the problem rather than part of the solution at the time of major environmental crises. As will be demonstrated there is increasing anger across Iran and there is no evidence yet to suggest that the Islamic Republic has an effective plan to find a lasting solution for the emerging crisis. Farmers and herders are regularly protesting and hold the state responsible for their plight. In some provinces, there have been shortages of drinking water which already has sparked violent demonstrations. Some of the worst affected provinces such as Khuzestan and Sistan-Baluchestan are mainly populated by ethnic minorities who evalu- ate these pressing environmental challenges as the extension of state dis- crimination against them. The rivers are drying, the lakes are shrinking, the underground water sources are diminishing, and the rapid expansion of deserts and drought are emptying the countryside and putting too much stress on unsustainably growing cities which are overwhelmed by hori- zontal inequality, pollution, unemployment, poverty, and the ever- increasing political divide. This is happening at the time that the external pressures are mounting too. The American sanctions are suffocating the national economy which is only causing the situation to deteriorate. All these problems are intertwined which are significantly increasing the cost of maintaining security for the Islamic Republic. But the question is whether the state has the political resilience to overcome these pressing challenges? In a situation in which the Islamic Republic is facing mul- tiple challenges can extreme drought be the Achilles Hill of a political regime which has survived numerous crises in its four decades of existence?

This article begins by highlighting the ecological challenges in the region. It will briefly discuss the ways in which factors such as drought have trigged political instability in the neighbouring countries. Indeed, paying some attention to the regional context can provide a better understanding of the nexus between environment and political instability. Then by collecting data from a wide range of primary and secondary sources including reports from governmental and nongovernmental organizations, press releases and scientific studies this paper sheds light on the overwhelming environmental challenges in Iran which are often overlooked both by policymakers and academics. Although establishing a factual ground about the situation is important, this paper goes beyond identifying the severe environmental challenges facing the country at the moment. In the final section, there is a discussion of the question of political resilience in order to critically evaluate whether the Islamic Republic is prepared to face the devastating ecological crisis and its socio-economic consequences.

\section{The Middle East, drought and turmoil: from past to present}

The recent scientific studies in the Middle East have delivered a reminder that the region has always been vulnerable to devastating droughts. ${ }^{9}$ Historically, there has been a clear link between drought and political instability in the Middle East. Water has not been only a source of life, but also a major force behind the rise and the fall of civilisations. Just in the same way many great ancient cities were built around major reservoirs or water sources, various studies confirm that climate change and drought have been a main causal factor behind the collapse of many ancient societies within or close to the area that today we recognise as 'the Middle East'. ${ }^{10}$

About 7,000-5,000 years ago, the climate of the region stabilised, paving the way for the rise of civilisations along the Nile, Tigris, Euphrates, Indus and the Yellow River. Survival, resilience and continuity of these ancient river valley civilisations were contingent on factors such as seasonal rains for production of excess food. ${ }^{11} \mathrm{New}$ scientific evidence suggests that droughts and water scarcity paved the way for the collapse of many ancient entities such as Akkadian Empire, 
the Old Kingdom of Egypt and other civilisations within Mesopotamia and the wider Middle East. $^{12}$

Indeed, the region has been subject to severe water shortages in various historical stages and this has profoundly shaped its social and political fabrics for centuries. When life-giving resources such as water becomes scarce, it is not surprising that it has an impact on every facet of life. Drought undermines both agriculture and food production. Famine and food scarcity create social unrest and rapidly increase the cost of political stability. Lack of political stability paves the way to social upheavals such as revolutions, riots and civil wars.

Over the last four decades, droughts have become longer and more frequent in the Middle East, where fresh water resources are among the worlds' lowest and are still likely to deteriorate due to the rising temperature and climate change. Although water scarcity is already affecting over 40 per cent of the global population, the situation is particularly bad in the Middle East.

According to the World Resource Institute, of the 33 countries that are expected to face extreme water scarcity by 2040 , more than half are placed in the Middle East. ${ }^{13}$ Indeed, Seven out of ten most water-stressed countries in the world are located in the Middle East. ${ }^{14}$

This bleak environmental reality has caused much instability in the region. Of course, one cannot reduce a complex socio-political phenomenon such as the so-called Arab Spring to a single cause. But there is little doubt that environmental factors within and beyond the region played a major role in sparking the upheavals. For example, the winter drought in China which contributed to global wheat shortages had a detrimental impact on the bread prices in countries such as Egypt, which is one of the largest wheat importer in the world. ${ }^{15}$ The dry climate in the Middle East and the lack of sufficient agricultural production makes the region heavily dependent on food imports. Indeed, the top nine wheat importers are all in the Middle East and, not surprisingly, when the price of wheat increased it sparked violent protests in countries with a high dependency on food imports. ${ }^{16}$ Going beyond upheavals in Egypt which still continues, there is significant evidence highlighting the role of climate change in sparking the Syrian civil war. ${ }^{17}$ In recent years, the Eastern Mediterranean has been facing its worst drought in the last 900 years. ${ }^{18}$ This has caused extreme water shortages and the col- lapse of agriculture, which became an important catalyst for the conflict. Economic devastation, mass rural-urban migration, the inability of the growing cities to absorb the disfranchised farmers coupled with the lack of political resilience of the Syrian regime paved the way to the major socio-political unrest leading to the ongoing civil war. ${ }^{19}$ Although there were many other critical underlining socio-political factors, climate change and its consequences were important in setting the stage for the social unrest which led to one of the worst humanitarian tragedies of our time.

The protracted Yemen conflict also has a clear environmental dimension too. Both climate change and many decades of water mismanagement have made Yemen one of the most waterstressed countries in the world. Various studies confirm that drought and its social consequences were important triggers for the conflict in Yemen. ${ }^{20}$

\section{Iran drought and turmoil: from past to present}

Water scarcity has been a permanent feature of Iranian history. Indeed, water shortage has been a very important force in shaping the socio-political landscape of Iranian society for many centuries. Although from ancient times Iranians have developed some advanced water management systems such as qanat (underground canal systems), water scarcity has often played a role during important turning points throughout Iranian history. Homa Katouzian, one of the leading socio-political theorists of Iran, has identified water scarcity as one of the most important factors in shaping Iranian history and society. He argues that, historically, scat- tered 
water sources have created scattered communities that were vulnerable, and prone to despotism. This contributed to the development of a semi-permanent state of instability and insecurity within Iran (and other Eastern countries) in what Katouzian names a short-term society. ${ }^{21}$

Many important historical watersheds such as the fall of the Safavid dynasty (1501-1738) had some important ecological factors. The Safavid empire (the last great historical Iranian empire) gradually disintegrated not only because of the weakness of the latter Safavid monarchs but also due to major economic and military challenges which were often caused by drought and water scarcity. ${ }^{22}$ Following the fall of the Safavids until the establishment of the Pahlavi dynasty in the $20^{\text {th }}$ century very rarely there was a powerful central government, which could exercise meaningful control over the Iranian territories. Although there are many explanations for this, there is little doubt that water scarcity played a role. In the pre-industrialised world, governing systems were heavily dependent on the agricultural sector to extract surplus wealth that could sustain trade and pay for both the military and political bureaucracy ensuring continuity and stability. Therefore, periodical water scarcity and famine have always caused or intensified political turmoil in the country. Although there are still many competing accounts of the Iranian revolution in 1979, a closer examination of the environ- mental situation at the time indicates that drought also played a role in the escalation of the revolution. Prior to the revolution, a number of the provinces were facing droughts, which contributed to the sense of antagonism against the state and paved the way for a wider migration of dis- franchised farmers to the growing cities. ${ }^{23}$ The influx of the people from the countryside to the urban centres created a more fertile ground for the revolution as many of the marginalised migrants went to become the foot soldiers of the revolution.

\section{The pressing environmental challenges in Iran}

Two-thirds of Iran is either desert or mountains. Deserts make up more than 300,000 square kilometres of the country. In recent years Iran has been witnessing rapid desertification as much of the countryside continues to lose vegetation and soil. ${ }^{24}$ During non-drought years the annual precipitation averages about 27 centimetres, but it is uneven across the country. ${ }^{25}$ Around 14 per cent of the land receives more than 52 per cent of the rainfall. ${ }^{26}$ The most precipitation occurs in the north of the country along the Caspian Sea shore, while in some regions, there is no rainfall for most of the year. Sudden storms with heavy rains a few times a year may afford those areas with their entire annual precipitation. ${ }^{27}$ However, according to recent estimates, the rate of precipitation has reached its lowest point in more than 40 years. ${ }^{28}$ However, the problem is not only decreasing precipitation. The rate of evaporation in Iran is above the global average. Approximately two- thirds of rainfall evaporates before it can replenish rivers. ${ }^{29}$

By the regional standards, the current per capita water availability in Iran is slightly above the average $(1,300$ cubic metres) but is significantly below the global average $(7,000$ cubic metres).${ }^{30}$ However, what makes the situation vulnerable is the mismatch between water resources and demand. This is a problem which some experts refer to as 'water bankruptcy'. ${ }^{31}$ This term refers to a situation which water demand is far greater than the available water. In other words, a country becomes water bankrupt when it uses water beyond its means in order to meet developmental, agricultural, industrial and even political objectives and by this definition Iran is a water bankrupt nation. ${ }^{32}$

One of the main problems which is putting too much pressure on water resources in Iran is that its population that has expanded rapidly since the 1980s. Before the Iranian revolution in 1979, 
Iran's population was under 30 million. But, in the course of the past four decades, it has reached over 82 million. ${ }^{33}$ Although Iran ranks 18th in the list of countries by population, the rate of fertility in Iran is 1.8 births per woman, which is right now below the world average of 2.1 births. ${ }^{34}$ While the rate of population growth in Iran has decreased over the past six years, the country is still paying a big price for the massive baby boom in the 1980s. This rapid population boom, as well as having environmental consequences, has put significant pressure both on food industries and agriculture, which are heavily dependent on water.

Not surprisingly, environmental pressures, economic problems and underdevelopment in certain regions of the country have paved the way for a rapid migration from rural areas to urban centres. This mass internal migration, as well as having socio-political consequences, has serious implications for the distribution of vital natural recourses such as water. Today over, 75 per cent of the population live in urban areas, which means over $61,640,000$ people live in cities and towns. ${ }^{35}$ For example, the capital city of Tehran alone hosts 18 per cent of the entire population of the country. ${ }^{36}$ There are many other rapidly growing cities which are no longer sustainable as they host too many inhabitants without a matching infrastructure and a suitable ecology. The existing spatial distribution and growing concentration of population in large urban centres put an ever-increasing pressure on water supplies. In addition to unsustainable development and urbanisation, the water sources are under great pressure due to wasteful consumption.

In Iran, the average daily consumption of water is estimated at 250 litres per person, which is twice the global average and can reach up to 400 liters in some cities such as Tehran. ${ }^{37}$ Although in recent years the cost of water and energy has rapidly increased, water is still not expensive enough to deter wasteful usage. In addition to wasteful consumption,

the ageing infrastructure and network leakages, which range from 15 to 50 per cent in urban areas, are putting even a greater pressure on the sources. ${ }^{38}$ Having said that, only 7 per cent of water is used in Iran's domestic sector. ${ }^{39}$ Although the majority of the population live in urban centres, the agricultural sector in the rural area is putting the main pressure on water sources.

Despite the fact that most of Iran's water sources are designated for the agricultural sector, there are some fundamental challenges that impede satisfactory productivity in this sector. Some of these challenges are natural and overlooking them has only worsened the situation. According to a new scientific report which was published in Nature, Iran's land suit- ability for cropping is (million ha): very good 0.4 per cent (0.6), good 2.2 per cent (3.6), medium 7.9 per cent (12.8), poor 11.4 per cent (18.5), very poor 6.3 per cent (10.2), unsuitable 60.0 per cent (97.4), and excluded areas 11.9 per cent (19.3). ${ }^{40}$ In this light most of the land in the country is unsuitable for agriculture and if sustainable farming methods are not adopted, even the limited suitable land available for farming will be jeopardised.

The Nature report which was published in 2017 highlights that

In addition to overarching limitations caused by low precipitation, low soil organic carbon, steep slope, and high soil sodium content were the predominant soil and terrain factors limiting the agricultural land suitability in Iran. About $50 \%$ of the Iran's existing croplands are located in low-quality lands, representing an unsustainable practice. There is little room for cropland expansion to increase production but redistribution of cropland to more suitable areas may improve sustainability and reduce pressure on water resources, land, and ecosystem in Iran. ${ }^{41}$

Ever since the downfall of the Pahlavi regime in 1979, the radical foreign policy of the Islamic Republic at times has sparked harsh reactions from the regional and global players. American sanctions, which were imposed on Iran following the hostage crisis, heralded the beginning of decades of embargo. This has prioritised the idea of 'self-sufficiently' for the political elite in 
Iran. From the earliest days of the Islamic Republic, self-reliance in agriculture and food production has been ideologised and zealously placed at the top of self-sufficiency agenda. ${ }^{42}$ However, the rapid population growth and the prevailing ecological realties of the country did not go hand in hand with the aspirations of the regime. Although the state heavily invested in agriculture and provided massive subsidies to the farmers, the idea of self-sufficiency in food production has decisively failed. ${ }^{43}$ Today, Iran faces more food insecurity than 40

years ago, and the continuation of these top-down policies have paved the way to water bankruptcy in the country. In other words not only was the goal of self-sufficiency not obtained, but unsustainable agricultural policies have put more pressure on water sources, which is ironically creating food and water insecurity. ${ }^{44}$

The state heavily subsidises energy and water for the rural community and historically the farmers had very little incentive to adopt sustainable agriculture. Therefore, as long as water is available, the farmers opt for the most profitable crops for short-term gains while their farming methods could have a detrimental impact on the ecosystem. ${ }^{45}$ In recent decades the increasing temperatures, the drying rivers and the declining rain have pushed the farmers to rely more on groundwater extraction which demands either electricity or diesel to pump out water. Given the heavy state subsidies farmers dig deeper and deeper in search of underground water to meet their short-term production targets. ${ }^{46}$

However, in 2018, the country's environment chief, Isa Kalantari, admitted that Iran is facing a major crisis. He stated that

The excessive consumption of water, especially from groundwater is a threat and could have terrible social consequences ... If the situation is not brought under control, we would lose about 70 per cent of our cultivated land in a maximum of $20-30$ years. $^{47}$

He also added that, "we currently use about 100 percent of our renewable water ... according to global standards this figure should not be higher than 40 percent" ${ }^{48} \mathrm{He}$ also admitted that "Iran could not be self-sufficient in food production for its estimated 80 million people ... Even with state- of-the-art technology, Iran could only be completely self-sufficient to supply food for 5055 million people". ${ }^{49}$

Over the last 40 years, most governments in Iran have had a preoccupation with building dams in order to respond to the increasing water shortages in the country. As well as being the 'answer' for water insecurity, dams were physical symbols of advancement and 'selfsufficiency'. Following the end of the Iran-Iraq war in 1987, President Rafsanjani made 'reconstruction' the hallmark of his administration and building dams became an integral part of Rafsanjani's 'reconstruction' administration. ${ }^{50}$ The symbolic and popular status of dam building became an enduring element of the Islamic Republic's economic policies, to the

expense of Iran's environment and water resources. The main function of these dams was in providing electricity and drinking water to main urban centres and rural towns and had little benefit for agriculture. ${ }^{51}$ Rafsanjani's 'reconstruction' agenda soon lost any sense of perspective and (amongst other negative effects) building dams - any dam - became an end in itself and not the means for tangible and sustainable economic growth. This obsession for building had a grave long-term effect on Iran's environment and water resources, particularly in Khuzestan province, where Rafsanjani's reconstruction era set the stage for the water- bankruptcy of this once water-rich province. ${ }^{52}$ Furthermore, Rafsanjani envisaged a wider role for the Islamic Revolutionary Guard Corps (IRGC). From this point, the IRGC was given the green light to participate in major economic and reconstruction projects. This was the beginning for the IRGC 
and its associated firms to construct dams in major rivers, changing the historical water flows of Iran. This resulted in more corruption and favouritism which gave water preferences to powerful landowners and favoured certain communities while simultaneously moving billions of dollars from the public treasury to the IRGC's accounts. ${ }^{53}$ In other words, dam construction, as well as having symbolic value, provided opportunities for unaccountable institutions that were more driven by ideological zeal and financial incentives rather than following expert advice. In this light, hundreds of dams mushroomed across the country which profoundly undermined Iran's historical water flows. While before the revolution only 13 dams were constructed, after 1979, over 600 dam projects have been built. ${ }^{54}$ Lack of scientific assessments of the environmental, societal and economic impacts of these dams have paved the way to eutrophication (the presence of excess nutrients in bodies of water), the flooding of historic sites, forced migration, and sedimentation. Although President Rouhani is rolling back on what was once a core water management policy, the construction of hundreds of dams before him has already damaged the ecosystem.

\section{Rural-urban migration}

Drought is rapidly changing the social landscape in various parts of the country. One of the main consequences of water scarcity is forced migration from rural to urban areas. Over 20 per cent of the population work in the agricultural sector. ${ }^{55}$ The climate change and drought are pushing a large segment of the rural population out of work, and given the lack of alternative employment in the countryside, the impecunious farmers often move to the cities in search of employment. However, given the existing economic problems and high unemployment rates, the urban centres cannot offer viable opportunities to these people. This already has proved to be a very dangerous pattern both in Iran and the wider region.

Forced migration and internal displacement no longer can go unnoticed in Iran. The total desiccation of Lake Hamun, close to the Afghan border, is the symbol of this deadly process. Both drought and massive irrigation have completely destroyed an area that was fertile for both humans and a natural habitat for wildlife. For millennia, both humans and a wide range of species lived around Lake Hamun. However, from the mid- $20^{\text {th }}$ century, irrigated agriculture started to expand there radically. By 2002, drought and unsustainable practices turned the lake and its sur- rounding area around it into a mere wasteland. The population of 124 sur- rounding villages was forced to abandon the area and seek refuge elsewhere ${ }^{56}$ More recently the desiccation of lake Urmia has symbolised the pressing environmental crisis in Iran. Lake Urmia was second only to the Caspian Sea as the largest saltwater lake in the Middle East. However, in the course of 30 years both climate change and mismanagement have reduced its size by about 90 per cent. ${ }^{57}$ Although the climate change is partly responsible for this problem, scientists suggest that the main problem is the thousands of illegal wells and excessive dams and irrigation projects, which are diverting water-flow from tributary rivers to feed into unsuitable agriculture ${ }^{58}$ As the result of desiccation, the frequency of salt storms has increased. These salt storms sweep across the exposed lakebed, undermining the productivity of nearby agricultural lands and pushing farmers to move away. In 2018, The managing director of the Iranian National Institute for Oceanography, Vahid Chegini, warned that the drying of the lake will lead to sand and salt storms on 'a quarter of Iran's territory'. ${ }^{59}$ There have also been warnings about the 'displacement of millions' and mass migration if the crisis continues. ${ }^{60}$

Although in recent years the government of Hassan Rouhani has taken measures to save Lake Urmia, environmentally-induced displacement is on the rise. Millions have already moved to provincial towns and cities. Iranian officials claim that over 30,000 villages have been deserted in the course of half a century. ${ }^{61}$ Although factors such as poverty and uneven development are among the catalysts behind this radical transition, drought and climate change and their 
mismanagement have been the main forces behind the decline of the rural areas. Some provinces have been hit hard by drought, which has exacerbated rural-urban migration. For example, by 2011, 1,700 out of 3,500 villages in South Khorasan were abandoned and 4,000 out of 8,000 villages in Fars providence were deserted as well, due to drought and water scarcity. ${ }^{62}$ Local authorities in Fars province have admitted that they have taken emergency measures to deliver water to 750 villages with tankers, as under- ground water sources have ran out. ${ }^{63}$ They also said that there are 17 towns in Fars province, which are facing worse conditions and the authorities are already taking emergency measures. ${ }^{64}$ Former Iranian agriculture minister Issa Kalantari has warned that in less than 25 years as many as 50 million Iranians will need to be relocated. He famously has warned that water scarcity, if left unchecked, would make Iran so harsh that 50 million Iranians would leave the country altogether. ${ }^{65}$

In an interview in 2018, the Interior Minister, Abdolreza Rahmani Fazli, stated that, mass migration from southern and central parts to the northern parts of the country has already began and internal environmental refugees will change the social landscape of the country within the next five years and in ten years it can create human catastrophe. ${ }^{66}$ This echoes Isa Kalantri who has warned that, should there not be a radical change in water management in the country, in 25 years the entirety of the south and the east of Iran will be deserted. ${ }^{67}$

\section{Is drought the Achilles Heel of the Islamic Republic?}

There is little doubt that Iran is on the brink of environmental crisis, which is rapidly changing the social landscape. But can it also lead to the change of political landscape? In other words, can drought and climate change constitute an existential threat to the Islamic Republic? After all, environmental factors such as drought have played an important role in major turning points throughout Iranian history. Water scarcity has been identified as one of the main causal factors behind the downfall of the Safavids. Even the revolution in 1979 which paved the way to the establishment of the Islamic Republic had some environmental dimen- sions. By looking at the wider regional context, it is clear that drought was a causal factor behind social unrest and conflict both in Yemen and Syria. Therefore, one cannot rule out the potential threat of climate change for any political regime in the Middle East.

Having said that there are many countries around the world facing environmental crises, and it would be simplistic to assume that environ- mental challenges alone could lead into major social eruptions such as civil war, revolution and downfall of a political regime. Although climate change can trigger social unrest, it cannot easily constitute an existential threat in the absence of other conditions. Very often the level of political resilience of the state determines the strength of the regime to face the crises. As long as the state is politically resilient, its structural limitations in facing the environmental problems do not easily result in existential security challenges. For example, drought in Spain, Portugal and Australia do not easily translate into a major security challenge for these states. Of course, such droughts may cause major economic challenges for certain communities and may even put consider- able strains on the governments in power, but one cannot expect them to contribute to major upheavals such as the Syrian civil war, because these states enjoy political resilience. Therefore, before we determine the political resilience of the Islamic Republic in facing the pressing environ- mental challenges, it is imperative to briefly define what is meant by political resilience here.

The notion of resilience refers to "the ability of groups or communities to cope with external stresses and disturbances as a result of social, political and environmental change". ${ }^{68}$ Thus, political resilience "refers to the capacity of political organisations to adapt to, and evolve responses to, internal and external events, such as large inflows of migration, war, financial crisis, rapid changes in demographics, environmental change etc" ${ }^{69}$ However, political 
resilience should not only refer to the physical capacity of the state to evolve or transform itself in response to changes within its environment. There are many other factors, which contribute to the political resilience of the state to successfully manage and survive major crises.

Legitimacy is the first and foremost factor which should not be overlooked. Of course, there are multiple sources of legitimacy and outlining them is beyond the scope of this article. However, in the rudimentary sense of the term, political legitimacy gained through democratic participation works as a very effective measure to boost the political resilience of a state; the prospect of periodic changes of government strengthens the political processes, which is vital in minimising the danger of violent social eruption at the time of crisis. As long as the political process is transformative there is a lesser possibility of a social eruption. In this light, public perception of the state is a very important factor for political resilience. Even if a state may not necessarily be democratic, it can still be generally trusted by the grassroots. ${ }^{70}$ Factors such as transparency improve the sense of public trust, and opposing factors such as corruption and unaccountability and the high-level of dependency on violent mechanisms of social control significantly undermine the political resilience of the state. Different types of exclusionary politics which are structurally institutionalised undermine the long-term political resilience of the state too. For example, the nation-building model which is adopted by the state plays a very important role. An ethnic-based nation-building model which centres around one ethnic community in a multi-ethnic country perpetually undermines the political resilience of the state as marginalisation and discrimination only increase the cost of maintaining security particularly at the time of crisis. Ideological states are by definition exclusionary. Such states rationalise their power by implementing their ideology which creates a non-participative political climate with a governing system which is accountable to an ideology rather than people. Last but not least the general economic performance of the state also has an important role. Even in a repressive and ideological regime such as China, the state still maintains some legitimacy by providing transformative economic opportunities benefiting a wide segment of society.

With the above criteria in mind, one can argue that the Islamic Republic, 40 years after its establishment, cannot be considered as a politically resilient state.

There is little doubt among observers that the Islamic Republic is in crisis. There is enough evidence in place to assert that the ideological mission of the state has failed. ${ }^{71}$ Forty years of social engineering policies of the Islamic Republic has only widened the gap between the state and the civil society. ${ }^{72}$ The economy is failing, the Iranian currency lost 70 per cent of its value in 2018 and there has been, at least, a 50 per cent rise in the price of some food items. ${ }^{73}$ The cost of housing in Tehran has risen between 40 and 60 per cent in the same year. ${ }^{74}$ Major industries such as vehicle manufacturers have reduced output by 40-50 per cent and some reports suggest that one million Iranians would lose their jobs as a result of economic pressures caused by renewed US sanctions against Iran. ${ }^{75}$ At the same time, public anger at elite corruption grows rapidly. ${ }^{76}$ Transparency International ranks Iran 130 out of 180 as corruption has become deeply endemic in the country. ${ }^{77}$ Unaccountable institutions such as the Revolutionary Guards have used their power to monopolise a large segment of the economy and many figureheads of the Islamic Republic have been accused of corruption and nepotism. ${ }^{78}$ Following widespread protests in winter 2018, the head of the judiciary, Ayatollah Sadeq Larijani, was appointed by the Supreme Leader to lead the fight against corruption. This act did not buy the regime much legitimacy because Larijani himself is accused of having corruptly amassed $\$ 300$ million in personal wealth. $^{79}$

The legitimacy of the Islamic Republic had already been significantly undermined by the ensuing crisis of Iran's 2009 presidential election. The country witnessed the biggest political protest since 1979. Millions of Iranians protested against the rigged election and the security forces responded with a heavy hand. Hundreds of people were killed, and thou- sands were 
arrested.$^{80}$ Although this created a legitimacy crisis for the Islamic Republic, in the following presidential election in 2013 Hassan Rouhani persuaded the reform-minded voters back to the voting booth in his favour. In his first presidential term, he focused on foreign policy to reach the Joint Comprehensive Plan of Action (JCPOA) to bring an end to decades of dispute with the US, and European powers along with China and Russia over Iranian nuclear activities. Although Rouhani was re-elected for the second time in 2017, there has been a lot of discontent about his second presidential term. Only one year into his second term public opinion has shifted against him as he was unable to deliver the reforms he promised during his electoral cam- paign. ${ }^{81}$ Arguably, this created an unprecedented level of disillusionment among the people who believed that by using the Islamic Republic's own political process they eventually could push for a transformative reform. Indeed, the inability of President Rouhani to deliver change has only deepened the legitimacy crisis of the Islamic Republic.

The year 2018 started with the most widespread protests in Iranian history since 1979. Unlike the 2009 protests, the demonstrations were not sup- porting the reform programme. They used slogans against the supreme leader and the entirety of the Islamic Republic. There were even calls for the return of the monarchy, unprecedented over the last four decades. ${ }^{82}$ Although the security forces eventually suppressed the December 2017-January 2018 demonstrations, the following 11 months proved to be turbulent for the regime. There have been numerous strikes and demonstrations across the country. At the same time, the security establishment has increased its crackdown on dissidents, which has increased the regime's dependence on violent mechanisms of social control. Summer 2018 put further strains on the Iranian security apparatus as there were numerous demonstrators protesting against the crumbling economy. The overwhelming economic pressures were coupled with shortages of drinking water, which sparked violent protests in various parts of Iran particularly in the cities of Abadan and Khorramshahr. ${ }^{83}$ Abadan and Khorramshahr are located within the oil-rich southwestern Khuzestan province, where the majority of Iran's ethnic Arab minority live. In recent years there have been more tensions between the Arab community and the state. Some members of the Arab community have long complained of discrimination and crackdowns by security forces. ${ }^{84}$ Throughout 2018, there were a number of clashes between angry farmers and security forces in badly-affected provinces such as Khuzestan and Isfahan. ${ }^{85}$ Both politically and economically, the Islamic Republic is suffering from fatigue. Yet the pressing ecological problems will put more strains on the regime. Many disfranchised farmers see the regime as being responsible for their plight. They want water and the regime cannot deliver. Although the majority of the people live in the urban centres, 20 million people still depend on the rural economy, which is under devastating ecological pressure and the state cannot do much about it. Tens of thousands of villages have been already deserted and the impoverished migrants often have little choice but to live in miserable conditions in unsustainable cities.

Given the severity of these pressing environmental challenges, the state does not seem to show any willingness to find a lasting solution. Addressing a conference on "Environmental Hazards and Regional Security in West Asia”, Iran's Deputy Foreign Minister, Abbas Araqchi, argued that critical water and environmental conditions 'should be viewed within the framework of security'. He regarded water as a 'strategic commodity' for which 'strategic action needs to be taken'. ${ }^{86}$ However, in practice the government has not taken any serious measures which could qualify as 'strategic action' to address these fundamental problems. For example, in the budget of 2018, the combined budget of frontline institutions such as the Environment Protection Organisation and the Organisation for Research, Education \& Agriculture Promotion did not match the money provided to the Ministry of Intelligence ${ }^{87}$ The overall budget for state-funded religious organisations, which promote Islamic teaching and state's ideology was 13 times bigger than the money allocated for the environment. ${ }^{88}$ While the country is on the brink of a major environmental crisis, the government increased the IRGC's suggested budget by 42 per 
cent, parallel to a 33 per cent elevation of the defence budget, ${ }^{89}$ and thus the IRGC received $\$ 8$ billion from Iran's fiscal budget. ${ }^{90}$ This happened at the same time that some of the high-ranking officials of IRGC have described the occurrence of climate change as a foreign conspiracy and the 'enemies' attempt to steal Iran's clouds. ${ }^{91}$ Clearly, this does not show a serious commitment to tackle a problem, which is effectively changing the social landscape of the country.

In conclusion, one cannot predict the consequences of these rapid changes as the pressure on the Islamic Republic is mounting by the day. Both economic and political shortcomings have created a crisis of legitimacy which in turn has undermined the political resilience of the state. Although the Islamic Republic portrays the image of stability, it lacks the necessary political resilience to face major crises. Forty years after its establishment, the Islamic Republic has lost the reliable social base it enjoyed in the early years of its existence. As the regime is losing more legitimacy, it has to increasingly rely on the violent mechanism of social control to preserve the status quo. However, in the absence of a transformative political process, there will be always a limit to the power of the security apparatus to guarantee political stability. Although the Islamic Republic is battle tested, today it is suffering from chronic fatigue. There is no easy solution for the pressing ecological problems which are entangled with other political, social, economic and security challenges. There is growing anger on almost every front, but drought more than anything is posing a long-lasting threat. As water scarcity is becoming more desperate the protests and clashes between the state and the people are becoming more widespread. Indeed, as the situation is deteriorating, one could expect a more radical course of action from the communities who are at the risk of losing their livelihood. Therefore, there is little doubt that drought is the Achilles heel of the Islamic Republic. Yet survival and continuity of any political regime depend on many variables. Although the Islamic Republic cannot be seen as a politically resilient regime, by no means will the unrelenting challenges inevitably make it collapse. It means the cost of maintaining security has become significantly higher for the Islamic Republic. The paralyzing economic crisis, a political cul de sac and the rapid change of social landscape caused by drought will make the regime increasingly weaker and these multifaceted challenges more pressing.

\section{NOTES}

1. 'Iran's Water Crisis', Aljazeera; People \& Power, November 13, 2016. https:// www.aljazeera.com/programmes/peopleandpower/2016/11/iran-water-crisis- 161109114752047.html (accessed 3 January 2019).

2. Najmeh Bozorgmehr, 'Iran: Dried Out'. Financial Times, August 21, 2014. https:// www.ft.com/content/5a5579c6-0205-11e4-ab5b-00144feab7de (accessed 3 January 2019).

3. Ibid.

4. 'Iran Facing Race Against Time to Tackle Water Crisis'. Press TV, January 28,

2018. https://www.presstv.com/Detail/2018/01/23/549903/Iran-economy-water-

shortage-dams (accessed 3 January 2019). 5. Ibid.

\section{DROUGHT}

6. Ibid.

7. Ibid.

8. Tzvi Khan, 'In Iran's Water Crisis, Tehran Sows the Seeds of It's Own Decline'. The Hill, May 26, 2018. https://thehill.com/opinion/international/389131-in-iranswater-crisis-tehran-sows-the-seeds-of-its-own-decline (accessed 3 January 2019). 
9. Tim Radford, 'Iranian Cave Warns of 10000 Years of Drought'. Climate News Network, July 11, 2017. https://climatenewsnetwork.net/iranian-cave-warns-of-

10000-years-of-drought/ (accessed 3 January 2019).

10. David Kaniewski, Elise Van Campo, Joël Guiot, Sabine Le Burel, Thierry Otto and

Cecile Baeteman, 'Environmental Roots of the Late Bronze Age Crisis'. Plos One, August 14, 2013.

https://journals.plos.org/plosone/article?id=10.1371/journal.pone. 0071004 (accessed 3 January 2019).

11. Andrew Glikson, 'Climate and the Rise and Fall of Civilizations: A Lesson From the Past'. The Conversation, December 10, 2015. https://theconversation.com/climate- and-the-rise-and-fall-of-civilizations-a-lessonfrom-the-past-51907 (accessed 3 January 2019).

12. 'Decline of Bronze Age "Megacities" Linked to Climate Change'. PHYS.ORG, Uni- versity of Cambridge February 26, 2014. https://phys.org/news/2014-02-decline- bronze-age-megacities-linked.html (accessed 3 January 2019).

13. Andrew Maddocks, Robert Samuel Young and Paul Reig, 'Ranking the World's- Most Water-Stressed Countries in 2040'. World Resources Institute, 2015. http:// www.wri.org/blog/2015/08/rankingworld\%E2\%80\%99s-most-water-stressed- countries-2040 (accessed 6 June 2018).

14. Ibid.

15. Catlin E. Werrell, Francesco Femia and Anne-Marie Slaughter, 'The Arab Spring and Climate Change'. Center for American Progress, February 28, 2013. https:// www.americanprogress.org/issues/security/reports/2013/02/28/54579/the-arab- spring-and-climatechange/ (accessed 3 January 2019).

16. Ibid.

17. Afshin Shahi and Maya Vachkova, 'Eco-sectarianism: From Ecological Disasters to Sectarian Violence in Syria'. Asian Affairs Journal Vol. 49. Issue 3 (2018).

18. Ibid.

19. Ibid.

20. Afshin Shahi and Maya Vachkova, 'Water Security and the Rise of Eco-Sectarian Conflict in Yemen', in Iqbal Mujtaba (Ed.), Water Management: Social and Technological Perspective. The CRC Press, 2018.

21. Homa Katouzian, 'The Short-Term Society: A Study in the Problems of Long-Term Political and Economic Development in Iran'. Middle Eastern Studies Vol. 40. Issue 1 (2004): 1-22.

22. Rudi Matthee, Persia in Crisis: Safavid Decline and the Fall of Isfahan; Safavid Decline and the Fall of Isfahan. London: I.B Tauris \& Co, 2012, p. 231, 235 and 253.

23. '“Joz'ee’yāt-i Dah Doreh Khoshk'sālī dar Irān, Ostān'hāyi keh dar Vaz'ee’yat-i

Hoshdār-i Khoshk'sālī Gharār Dārand" Shodeh'and' [Some Details About 10 Drought Periods and Provinces Which are in Drought Alert. An Interview With

\section{DROUGHT 19}


Forūd Sharifi, President's Deputy of Science in Charge of Environment \& Water Development], Mehr News Agency, 8

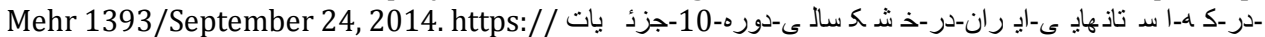

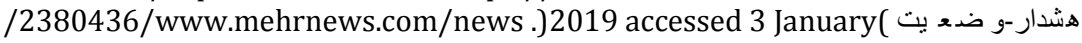

24. 24. 'Iran'. Nations Encyclopedia. https://www.nationsencyclopedia.com/geography/ Indonesia-toMongolia/Iran.html\#ixzz5b5d8elFZ (accessed 3 January 2019).

25. 25. Ibid.

26. 26. Ibid.

27. 27. Ibid.

28. 28. Ali Hajizade, 'Water Crisis in Iran: Causes, Consequences and Perspectives'. July 3 ,

2018. https://english.alarabiya.net/en/views/news/middle-east/2018/07/03/Water-

crisis-in-Iran-Causes-consequences-and-perspectives.html (accessed 3 January 2019).

29. 29. Ibid.

30. 30. Ibid.

31. 31. Kaveh Madani, Amir AghaKouchak and Ali Mirchi, 'Iran's Socio-economic Drought: Challenges of a Water-Bankrupt Nation'. Iranian Studies Vol. 49. Issue $.1016-997:) 2016(6$

32. 32. Ibid.

33. 33. 'Iran Population (Live)'. World Matters, http://www.worldometers.info/world- population/iranpopulation/ (accessed 3 January 2019).

34. 34. The United Nations, 'World Fertility Patterns 2015', http://www.un.org/en/ development/desa/population/publications/pdf/fertility/world-fertility-patterns- 2015.pdf (accessed 3 January 2019).

35. 35. 'Iran Population (Live)', World Matters, http://www.worldometers.info/ worldpopulation/iranpopulation/ (accessed 3 January 2019).

36. 36. Madani, AghaKouchak and Mirchi, 'Iran's Socio-economic Drought', p. 999.

37. 37. Ibid.

38. 38. Ibid.

39. 39. Ibid.

40. 40. Mohsen B. Mesgaran, Kaveh Madani, Hosseing Hashemi and Pooya Azadi, 'Iran's Land Suitability for Agriculture'. Scientific Reports, December 2017. https://www.nature.com/articles/s41598-017-08066-y (accessed 3 January 2019).

41. 41. Ibid.

42. 42. Ali Shokoori, The State and Rural Development in Post-Revolutionary Iran.

New York: Palgrave Macmillan, 2001, p. 4, 72 and 125.

43. 43. Madani, AghaKouchak and Mirchi, 'Iran's Socio-economic Drought', p. 1000.

44. 44. Ibid.

45. 45. Ibid, 1002.

46. 46. Ibid.

47. 47. 'Iran Risks Losing 70\% of Farmlands: Environmental Chief'. France 24, November 5, 2018, https://www.france24.com/en/20181005-iran-risks-losing-70-farmlandsenvironment-chief (accessed 3 January 2019).

48. 48. Ibid.

49. 49. Ibid.

\section{DROUGHT}

50. 'How Iran's Khuzestan Went From Wetland to Wasteland'. The Guardian, April 16, 2015. https://www.theguardian.com/world/iran-blog/2015/apr/16/iran-khuzestan- environment-wetlandsdust-pollution (accessed 3 January 2019). 
51. Ali Shokoori, The State and Rural Development in Post-Revolutionary Iran. p. 103.

52. 'How Iran's Khuzestan Went From Wetland to Wasteland'. The Guardian, April 16, 2015. https://www.theguardian.com/world/iran-blog/2015/apr/16/iran-khuzestan- environment-wetlandsdust-pollution (accessed 3 January 2019).

53. Seth M. Siegel, 'Forget the Politics. Iran Has Bigger Problems'. Washington Post, May 16, 2017. https://www.washingtonpost.com/news/democracy-post/wp/2017/ 05/16/forget-the-politics-iran-hasbigger-problems/?noredirect=on\&utm_term=. e573073ddb1d (accessed 3 January 2019).

54. Monavar Khalaj, 'Iran's Rouhani Rolls Back on Dam Projects'. Financial Times, March 19, 2015. https://www.ft.com/content/56704462-ccb7-11e4-b5a5- 00144feab7de (accessed 3 January 2019).

55. Madani, AghaKouchak and Mirchi, 'Iran's Socio-economic Drought', p. 999.

56. 'Special Report on the Hamun Lake Crisis'. IRIN, September 25, 2002. http://www. irinnews.org/feature/2002/09/25/special-report-hamun-lake-crisis (accessed 3

January 2019).

57. Kennet R. Weiss, 'Iran's Tarnished Gem', April 3, 2018. https://www.

nationalgeographic.com/photography/proof/2018/04/lake-urmia-iran-drought/

(accessed 3 January 2019).

58. Ibid.

59. 'Fears Over Prolonged Drought in Iran'. BBC, January 19, 2018. https://www.bbc. com/weather/features/42746372 (accessed 3 January 2019).

60. Ibid.

61. 'Bish az Sī Hezār Rūstā-i Irān dar Bish az Nim Gharn Gozashteh Khālī Shodeh'and'

[More than 30000 Iranian Villages Have Been Abandined in the Last 50 Years], Radio Farda, Persian, 25 Shahrivar 1395/September 8, 2016. https://www. radiofarda.com/a/f2-iran-villages-in-thousandswithout-residents-rohani- government/27990064.html (accessed 3 January 2019).

62. Niki Mahjoub, 'Mohjerān Khoshk'sālī dar Irān beh Donbāl-i Sarpanāh' [Iran's Drought Refugees in Search of Sanctuary], BBC Persian, 8 Shahrivar 1397/ August 30, 2018. http://www.bbc.com/persian/45281646 (accessed 3 January 2019).

63. 'Enāyat'ollāh Rahimī, Mas'ool-i Omūr-i Omrānī Ostān-i Fārs: Āb-i Āshāmidanī-i Mored-i Niyāz-i Haftsado Panjāh Rūstā Bā Tānker Ta'meen Mishavad' [Head of Fars Province's Water Bureau: The Drinking Water of More than 750 Villages are Delivered by Tankers], Radio Zamaneh, 18 Mordad 1397/August 5, 2018. https://www.radiozamaneh.com/406899 (accessed 3 January 2019).

64. https://www.radiozamaneh.com/406899 (accessed 3 January 2019).

65. Arash Karami, 'Iran Official Warns Water Crisis Could Lead to Mass Migration', Al-Monitor, April 28, 2015. https://www.al-monitor.com/pulse/fr/originals/2015/

04/iran-water-crisis-mass-migration.html (accessed 3 January 2019).

\section{DROUGHT 21}

66. 'Vazir-i Keshvar: Panj Sāleh Digar Mohāieat-i Eghlim Chehrey-i Irān rā Tagh'yir Midahad' [Iran’s Interior Minister: In Five Years Environmental Migrations Will Change the Face of Iran], Radio Farda, 7 Mordad 1397/July 29, 2018. https:// www.radiofarda.com/a/iranianinteriorminister-drought-emigration/29396926.html.

67. Ibid.

68. W. Neil Adger, 'Social and Ecological Resilience: Are They Related?'. Progress in

Human Geography Vol. 24. Issue 3 (September 2000): 374-364.

69. Joss Colchester, 'Political Systems Resilience'. Complexity Labs, July 4, 2017.

https://complexitylabs.io/political-systems-resilience/ (accessed 3 January 2019).

70. For example, in a small country like Qatar, the grassroots seem to be satisfied with 
the rentier state.

71. Afshin Shahi and Alam Saleh, 'Andalusiasation: Is Iran on the Trajectory of De-Isla-

misation?' The British Journal of Middle East Studies Vol. 42. Issue 4 (2015).

72. Ibid.

73. Ladan Nasseri, Golnar Motevalli and Arsalan Shahla, 'After Sanctions, Iran's Economy Is Nearing a Crisis', August 9, 2018. https://www.bloomberg.com/ news/articles/2018-08-09/as-sanctions-hit-iran-s-on-theverge-of-economic- breakdown (accessed 3 January 2019).

74. 'Economic Crisis in Iran Leading to Job Cuts and Inflation'. Radio Farda, August 15, 2018. https://en.radiofarda.com/a/iran-economic-crisis-inflation-jobs/29435184. html (accessed 3 January 2019).

75. Ibid.

76. Monavar Khalaj, 'Iranian Anger at Corruption Grows as Sanctions Bite'. Financial

Times, August 27, 2018. https://www.ft.com/content/80aebcce-a772-11e8-8ecf-

a7ae1beff35b (accessed 3 January 2019).

77. 'Iran'. Transparency International, https://www.transparency.org/country/IRN

(accessed 3 January 2019).

78. Afshin Shahi and Hesam Forozan, 'The Military and the State in Post-Revolutionary

Iran: The Economic Rise of the Revolutionary Guards'. The Middle East Journal

Vol. 71 (January 2017).

79. Holly Dagres, 'Iranian Crackdown on Corruption May Only Be Superficial'. Atlan-

tic Council, October 12, 2018. https://www.atlanticcouncil.org/blogs/iransource/ iranian-crackdown-oncorruption-may-only-be-superficial (accessed 3 January 2019).

80. Julian Borger and Ian Black, 'World Leaders urged by Iran's Opposition Party to Reject Ahmadinejad's Alleged Victory'. The Guardian, June 14, 2009. https:// www.theguardian.com/world/2009/jun/14/iranahmadinejad-mousavi-elections- result (accessed 3 January 2019).

81. Sofia Patel, 'Rouhani-Why is Iran's Reformer Not Reforming?' The Strategist, Feb- ruary 5, 2018. https://www.aspistrategist.org.au/rouhani-irans-reformer-not- reforming/ (accessed 3 January 2019).

82. Saeed Kamali Dehghan, 'Rouhani Acknowledges Iranian Discontent as Protests Continue'. The Guardian, December 31, 2017. https://www.theguardian.com/ world/2017/dec/31/protesters-who-spread-fearand-violence-will-be-confronted- says-iran (accessed 3 January 2019).

\section{DROUGHT}

83. 83. 'Authorities Admit At Least 11 Injured in Protests Over Lack of Water'. Radio Farda, July 1, 2018. https://en.radiofarda.com/a/khorramshahr-water-protests- turn-violent-/29330047.html (accessed 3 January 2019).

84. 84. Alam Saleh, Ethnic Identity and the State in Iran. New York: Pelgrave Macmillan, 2013, pp. 70-72 and 112-115.

85. 85. Babal Dehghanpisheh, 'Water Crisis Spurs Protests in Iran'. Reuters, March 29,

2018. https://www.reuters.com/article/us-iran-security-water-crisis/water-crisis- spurs-protests-in-iranidUSKBN1H51A5 (accessed 3 January 2019).

86. 86. 'Explainer: Iranian Drought Raises Environmental Alarm'. BBC, January 17, 2018. https://monitoring.bbc.co.uk/product/c1 dooomk (accessed 3 January 2019). 
87. 87. Heshmat Alavi, 'A Close Look at Iran's Budget'. Forbes, March 1, 2018. https:// www.forbes.com/sites/heshmatalavi/2018/03/01/a-close-look-at-irans-budget/ \#74f8aac56e1e (accessed 3 January 2019).

88. 88. 'Būdje-i Novado Hasht; Sahm-i Nahādhāy-i Mazhabī va Tablighātī Sizdah Barābar- i Mohit-i Zist Ast' [Iran's 2019 Budget; The Share Religious \& Propaganda Insti- tutions is 13 Times More than Environmental Agency]. BBC Persian, December 30, 2018. http://www.bbc.com/persian/iran-features-46716263 (accessed 3 January 2019).

89. 89. Ibid.

90. 90. Ibid.

91. 91. 'Rayis-i Sāzmān-i Padāfand-i Gheir-Āmel: Taghyirāt-i Eghlimī Irān Mashkūk Ast/

Abr'hāyeh Irān rā Midozdand' [Revolutionary Gurrd's General in Charge of Iran's Stationary Defense Organization: Iran's Environmental Changes are Suspicious/ Our Clouds Are Being Stolen] ISNA, July 2,

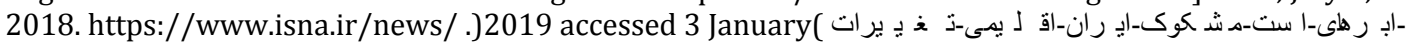

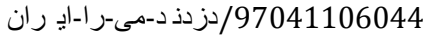

